\title{
Sales de sulfato magnésico y materiales de edificios históricos: simulación experimental de laminaciones en calizas mediante ciclos de humedad relativa y cristalización de sales
}

\section{Magnesium sulfate salts and historic building materials: experimental simulation of limestone flaking by relative humidity cycling and crystallization of salts}

\author{
P. Lopez-Arce $^{(*)}$, E. Doehne ${ }^{(*)}$, W. Martin ${ }^{(* *)}$ y S. Pinchin ${ }^{(* *)}$
}

Recepción/Received: 31-V-07

Aceptación/Accepted: 14-XI-07

Publicado online/Online publishing: 20-XII-07

\section{RESUMEN}

Las sales de sulfato magnésico a menudo se producen a partir de la combinación de materiales de construcción incompatibles que, cuando se combinan con una fuente de humedad, reaccionan para formar sales solubles que con frecuencia dan lugar a un importante deterioro por laminaciones de la piedra. Varios experimentos de laboratorio se llevaron a cabo para reproducir laminaciones superficiales en calizas y evaluar los efectos de ciclos de humedad en el deterioro de la piedra por cristalización de sales. Se utilizaron dos soluciones salinas: una única sal de sulfato magnésico y una mezcla de sulfato magnésico, sulfato cálcico y cloruro sódico. Se utilizó una cámara climática para probar la hipótesis de que el deterioro por sales en la piedra puede ser fácilmente causada por fluctuaciones de humedad. El deterioro por laminaciones se produjo aparentemente, por la formación de sales delicuescentes de baja HReq, en dos tipos de calizas magnésicas impregnadas con la mezcla salina, mientras que el resto de las muestras desarrollaron una costra salina sobre la superficie pero sin observarse deterioro. Mediante la combinación de datos de campo y de laboratorio se puede obtener una mejor comprensión de los diferentes mecanismos de deterioro y tipos de alteración asociados bajo diferentes condiciones ambientales.

Palabras clave: sulfato magnésico, caliza, laminaciones, deterioro salino, ciclos de humedad.

\section{SUMMARY}

Magnesium sulfate salts often result from the combination of incompatible construction materials that, when combined with a source of moisture, react to form soluble salts often leading to significant damage by flaking of the stone. Several laboratory experiments were performed to reproduce surface flaking on limestone and to evaluate the effects of humidity cycling on the damage of stone by salt crystallization. Two salt solutions were used: a single salt of magnesium sulfate and a mixture of magnesium sulfate, calcium sulfate and sodium chloride. A climate chamber was used to test the hypothesis that salt dama$g e$ in the stone can be readily caused by humidity fluctuations. Damage by flaking apparently took place, by formation of deliquescent salts of low RHeq, in two types of magnesian limestone cubes impregnated with the salt mixture, while the rest of the samples developed a salt crust over the surface, but no damage was observed. By combining both, field and laboratory data, a clearer understanding the different mechanisms of decay and associated weathering types under different environmental conditions can be obtained.

Keywords: magnesium sulfate, Limestone, flaking, salt decay, humidity cycling.

\footnotetext{
(*) The Getty Conservation Institute (Los Angeles, USA).

(**) English Heritage (London, UK).
} 


\section{INTRODUCCIÓN}

El sulfato magnésico hepta-hidratado $\left(\mathrm{MgSO}_{4} \cdot 7 \mathrm{H}_{2} \mathrm{O}\right)$ se conoce también como epsomita y más comúnmente como sal de Epson. En contraste con el papel beneficioso que puede jugar en la salud de los humanos, su papel destructivo en el deterioro de la piedra utilizada en edificios, monumentos y emplazamientos históricos se documenta en este trabajo mediante una breve revisión bibliográfica reportando una selección de publicaciones sobre el tema.

Las fuentes del sulfato magnésico dentro de los materiales de edificios históricos se relacionan con: (i) el suelo subyacente que puede contener sales que se introducen mediante el proceso de ascensión de humedad por capilaridad (1); (ii) el viento en forma de brisa marina salina (2) o gases volcánicos; (iii) inundaciones (3); (iv) sales procedentes del origen geológico de la piedra $(4,5) ;(v)$ metabolismos biológicos (6); (vi) uso de sales para descongelación; (vii) almacén de sal (7) o uso de sales de Epsom para el baño en termas antiguas; (viii) componentes de materiales de construcción o conservación añadidos involuntariamente, p. ej. el uso de yeso en morteros para mejorar su trabajabilidad y acelerar el tiempo de secado o el uso de agua marina para prepararlos (8); (ix) la contaminación atmosférica, por reacción de los gases de $\mathrm{SO}_{2}$ y $\mathrm{NO}_{x}$ con la composición original de los materiales de los edificios, p. ej. la reacción de $\mathrm{SO}_{2}$ con la piedra caliza (carbonato cálcico) dará lugar a la formación de yeso (sulfato cálcico), mientras que su reacción con piedra dolomítica o caliza magnésica (carbonato cálcico y magnésico) dará lugar a la formación de sales de sulfato cálcico y magnésico (4).

Mientras que el sulfato cálcico normalmente forma costras sobre la superficie de la piedra, el sulfato magnésico es más soluble y por tanto más móvil que el yeso. El sulfato magnésico es fácilmente lavado por la lluvia en aquellas zonas que quedan expuestas, pero en áreas protegidas permanece en contacto con la piedra pudiendo también penetrar más a fondo dentro de la misma, jugando así una parte importante en la causa de deterioro (9-11). Las zonas protegidas pueden también actuar como superficies de secado, arrastrando sales de otras partes de la estructura, ya que la humedad es transportada con regularidad procediendo de áreas adyacentes sujetas a humedecimientos periódicos.

En contra de las causas naturales de la incorporación de sales procedentes del suelo (ascenso de humedad capilar), del viento (brisa marina) y del agua (inundaciones), otras causas de intrusión de sales están directamente relacionadas con la composición de los materiales de los edificios, donde la estructura porosa de los mismos jugará también un papel clave en el mecanismo de deterioro

\section{INTRODUCTION}

Magnesium sulfate heptahydrate $\left(\mathrm{MgSO}_{4} \cdot 7 \mathrm{H}_{2} \mathrm{O}\right)$ is also known as epsomite and more commonly as Epsom salt. In contrast to the beneficial role it may play in human health, its destructive role in the damage of stone used in historic buildings, monuments and sites is documented here with a brief literature review covering selected publications on the topic.

The sources of magnesium sulfate within historic building materials relate to: (i) the underlying soil which can contain salts introduced by the process of rising damp (1); (ii) the wind in the form of marine salt spray (2) or volcanic gases; (iii) floods (3); (iv) salts from the geological origin of the stone $(4,5) ;(v)$ biologic metabolisms (6); (vi) use of de-icing salts; (vii) storage of salt (7) or use of Epsom bath salts in ancient thermae; (viii) inadvertently added components of construction or conservation materials, e.g. the use of gypsum in mortars to improve their workability and to accelerate the drying time or the use of seawater to prepare them (8); (ix) the atmospheric pollution, by the reaction of $\mathrm{SO}_{2}$ and $\mathrm{NO}_{x}$ gases with the original composition of building materials, e.g. $\mathrm{SO}_{2}$ reacting with limestone (calcium carbonate) will form gypsum (calcium sulfate), while its reaction with dolostone or magnesian limestone (both calcium and magnesium carbonate) will form calcium and magnesium sulfate salts (4).

While calcium sulfate usually forms crusts over the surface of the stone, magnesium sulfate is more soluble and thus more mobile than gypsum. Magnesium sulfate is readily washed away by rain from suitably exposed positions, but in sheltered areas it remains in contact with the stone where it can also penetrates further into the stone, thus playing a prominent part in causing decay (9-11). Sheltered zones may also act as drying surfaces, drawing salts from other parts of the structure, as moisture is regularly transported from adjacent areas subject to periodic wetting.

In contrast to the natural causes of salts ingress from the soil (rising damp), from wind (marine spray) and water (floods), other causes of salt input are directly related to the building materials composition, where the pore structure will also play a key role in the mechanism of decay (12 and 13). The viscosity of sodium and magnesium sulfate salt solutions can be also critical in the crystallization 
(12 y 13). La viscosidad de las disoluciones salinas de sulfato sódico y magnésico puede ser también crítica en la cristalización de estas sales en calizas porosas (14). En muchos casos, la mineralogía de los materiales de los edificios es un factor importante en la formación de sales, precipitadas a partir de las reacciones químicas entre los iones procedentes de un mortero o una piedra, o de la combinación de estos iones con material procedente de la contaminación aérea depositada por el viento o la lluvia.

La fuente de los cationes de magnesio presentes en las eflorescencias de sulfato magnésico está fuertemente relacionada con la composición de los materiales de los edificios utilizados para construcción: sea dolomita o calizas magnésicas, mármoles dolomíticos, esquisto verde, serpentina, granito y/o morteros elaborados con cal dolomítica (óxidos de $\mathrm{Mg}$ y $\mathrm{Ca}$ ).

La relativa facilidad de disolución del cristal de dolomita puede ser también un factor importante en las diferencias de durabilidad observadas entre diferentes calizas magnésicas, ya que la dolomita rica en calcio puede ser mucho más soluble que la dolomita estequiométrica (15).

Caner et al. (16), encontraron eflorescencias de epsomita y hexahidrita formadas en las zonas de secado de la piedra dolomítica de la Gran Mezquita de Divrigi-Turquía. Observaron también pulverización de la piedra en las superficies expuestas y la formación de grietas por debajo de las mismas, seguido de la pérdida de fragmentos del tamaño de una mano o mayores. En su investigación de laboratorio, descubrieron que la disolución de dolomita da lugar a la liberación de iones de magnesio cuando la piedra está expuesta a un medio alcalino con o sin iones de sulfato.

Con la finalidad de determinar las principales causas que producen laminaciones y desconchamientos debido al ataque por sulfatos en las baldosas de piedra serpentina (con contenido muy alto en $\mathrm{Mg}$ debido a la clorita) utilizadas en el convento de las Descalzas Reales de Madrid (España), Blanco-Varela y Hoyos (17) llevaron a cabo experimentos de laboratorio mediante la inmersión de prismas de serpentina en una solución saturada de sulfato cálcico. Los autores dedujeron que se producía un intercambio iónico Ca-Mg en la presencia de iones de $\mathrm{SO}_{4}{ }^{2-}$ y $\mathrm{Ca}^{2+}$, permitiendo la cristalización de sulfato magnésico.

La alteración de esquistos verdes noruegos--utilizados en muchas iglesias entre 1100 y 1200 DC--en Trondheim, centro de Noruega (18), también dio lugar a la precipitación de sulfato de magnesio. La matriz de la piedra contiene minerales que llevan magnesio como clorita o biotita, así como granos y venas más grandes que tienen minerales ricos en magnesio como la dolomita. La piedra of these salts in porous limestone (14). In many cases, the mineralogy of the building materials is an important factor in the formation of salts, precipitated from the chemical reactions between the ions from a mortar and a stone, or from the combination of these ions with material from air pollution deposited by wind and rain.

The source of magnesium cations present in magnesium sulfates efflorescences is strongly related to the composition of the building materials used for construction: whether dolomite or magnesian limestones, dolomitic marbles, greenschist, serpentine, granite and/or mortars made with dolomitic lime (Mg and Ca oxides).

The relative ease of dissolution of the dolomite crystal may also be an important factor in durability differences observed between different magnesian limestones, since calcium-rich dolomite it can be much more soluble than stoichiometric dolomite (15).

Caner et al. (16), found efflorescences of epsomite and hexahydrite formed in the drying zones of the dolomitic stone in the Divrigi Great Mosque-Turkey. They also observed powdering of the stone at the exposed surfaces and the formation of cracks beneath, followed by the loss of hand-size or larger fragments. In their laboratory research, they found that the dissolution of dolomite results in the release of magnesium ions when the stone is exposed to an alkaline medium with or without sulfate ions.

In order to determine the main causes producing flaking and blistering due to sulfate attack of serpentine stone slabs (with very high Mg content due to chlorite) used in the Descalzas Reales convent at Madrid (Spain), laboratory experiments were carried out by Blanco-Varela and Hoyos (17) by immersion of serpentine prisms in a saturated solution of calcium sulfate. The authors deduced that there was an ionic interchange $\mathrm{Ca}-\mathrm{Mg}$ in the presence of the $\mathrm{SO}_{4}^{2-}$ and $\mathrm{Ca}^{2+}$ ions, allowing the crystallization of magnesium sulfate.

The weathering of Norwegian greenschist--used in many churches between 1100 and 1200 AD--in Trondheim, Central-Norway (18) gave rise to the precipitation of magnesium sulfate as well. The matrix of the stone includes magnesium-bearing minerals such as chlorite and biotite, as well as larger grains and veins bearing magnesium-rich minerals such as dolomite. The stone also con- 
también contiene pirita, la cual puede ser una fuente de azufre para la formación de sulfatos de magnesio. El autor consideró la piedra como una fuente para la precipitación de sales, además del cemento Portland procedente de las juntas de mortero y cimientos de construcción, y la contaminación aérea.

La fuente de aniones de sulfato en la formación de sulfatos de magnesio está a menudo relacionada con los morteros y la contaminación por $\mathrm{SO}_{2}$ atmosférico. En pocas situaciones, el origen de los aniones de sulfato no está claro. En estos casos, los estudios de trazadores geoquímicos utilizando isótopos estables pueden ayudar a identificar la fuente.

La combustión del carbón transforma el azufre en dióxido de azufre, uno de los principales contaminantes atmosféricos durante los últimos cuatro siglos. Calizas y areniscas calcáreas tienen tendencia a desarrollar costras de sulfato cálcico hidratado a partir de la reacción de la piedra húmeda (rica en carbonatos cálcicos) con el dióxido de azufre gaseoso que se convierte en ácido sulfúrico o en una sal de sulfito intermedia mediante una reacción de oxidación (11). Las superficies de estas piedras desarrollan una costra superficial de yeso, ennegrecida por la incorporación de partículas de hollín y materia orgánica.

El-Metwally y Ramadan (3) estudiaron el impacto de los gases de $\mathrm{CO}_{2}$ y $\mathrm{SO}_{2}$ sobre piedras dolomíticas procedentes del complejo Al-Ghuri (El Cairo, Egipto), obteniendo perfiles de profundidad que indicaban la presencia de sulfatos entre 100 y $1200 \mu \mathrm{m}$ bajo la superficie de la piedra. El uso de morteros de yeso es común en Egipto y puede ser otra fuente de sulfato en este caso.

Las principales fuentes de sales de sulfato magnésico en edificios históricos son las reacciones químicas entre materiales de construcción incompatibles: dolomita o caliza magnésica, así como morteros ricos en magnesio (por la cocción de carbonatos de magnesio) y morteros que contienen sulfatos cálcicos, o entre materiales de construcción ricos en magnesio y ambientes contaminados con $\mathrm{SO}_{2}(2,3,10,16,19-24)$.

Está claro el papel destructivo de las sales de sulfato magnésico en el deterioro de materiales de construcción porosos utilizados en edificios, monumentos y emplazamientos históricos. Para determinar mas claramente el alcance del problema, la fuente de estas sales móviles y el grado de deterioro, se inició un proyecto de investigación conjunto sobre caliza magnésica entre el Getty Conservation Institute (GCI) y el English Heritage centrándose en el lugar de Howden Minster, que sufre una extendida y rápida laminación de la piedra dolomítica. Trabajos previos de laboratorio habían mostrado que la cristalización de sulfato magnésico (epsomita) por ascen- tains pyrite, which may be a source of sulfur for the formation of magnesium sulfates. The author considered the stone as one source for the precipitation of salts, in addition to Portland cement from joints and masonry cores, and air pollution.

The source of sulfate anions in the formation of magnesium sulfates is often related to mortars and pollutionrelated atmospheric $\mathrm{SO}_{2}$. In a few examples, the origin of the sulfate anions is not clear. In these cases, geochemical tracer studies using stable isotopes may help to isolate the source.

Coal burning transforms sulfur into sulfur dioxide, one of the main atmospheric pollutants during the past four centuries. Limestones and calcareous sandstones are prone to developing crusts of hydrated calcium sulfate from the reaction of the moist stone (rich in calcium carbonates) with sulfur dioxide gas that has been converted to sulfuric acid or to an intermediate sulfite salt by an oxidation reaction (11). These stones surfaces develop a surface crust of gypsum, blackened by incorporation of soot particles and organic matter.

El-Metwally \& Ramadan (3) studied the impact of gaseous $\mathrm{CO}_{2}$ and $\mathrm{SO}_{2}$ on some dolomitic stones from the AlGhuri complex (Cairo, Egypt), obtaining depth profiles that indicated the presence of sulfates 100 to $1200 \mu \mathrm{m}$ below the stone surface. The use of gypsum mortars is common in Egypt and may be another source of sulfate in this case.

The main sources of magnesium sulfate salts in historic buildings are the chemical reactions between incompatible construction materials: dolomite or magnesian limestone, as well as magnesium-rich mortars (from burning magnesium carbonates) and mortars containing calcium sulfates, or between magnesium-rich building materials and $\mathrm{SO}_{2}$ polluted environments $(2,3,10,16,19-24)$.

The destructive role of magnesium sulfate salts in the damage of porous construction materials used in historic buildings, monuments and sites, is clear. In order to more clearly determine the scope of the problem, the source of these mobile salts and the extent of the damage, a joint research project was initiated on magnesian limestone between the Getty Conservation Institute (GCI) and the English Heritage focused on the site of Howden Minster, which suffers from widespread, rapid flaking of dolomitic stone. Previous laboratory work had shown that rising damp crystallization by magnesium sulfate (epsomite) causes extensive damage to porous limestone in 
so de humedad capilar causa gran deterioro en la caliza porosa en menos de un año. Uno de los objetivos de este trabajo es determinar sí la laminación de la caliza magnésica utilizada en Howden podría ser simulada en el laboratorio únicamente mediante ciclos de humedad, ya que el papel, la extensión y los cambios del agua líquida dentro del muro debido al ascenso capilar todavía no están claros.

\section{MATERIALES Y MÉTODOS}

Para evaluar el grado de laminación activa en el campo, en Howden Minster se realizaron análisis visuales mediante documentación fotográfica y la instalación de una cámara de campo con registro de intervalos de tiempo para correlacionar los sucesos de laminación con los cambios ambientales.

Con la finalidad de examinar como y en que grado las fases salinas están relacionadas con el deterioro, las sales se extrajeron a partir de tres fracciones de la superficie de muestras de la piedra alterada procedente de la parte superior del arco de elevación 16 (crujía 4 muro oeste) de Howden Minster; HBC16-A: piedra pulverizada; HBC16$\mathrm{B} 1$ : fragmentos de costra ennegrecida y $\mathrm{HBC16-B2:} \mathrm{frag-}$ mentos de laminaciones de piedra (Figura 1a). La extracción de sales solubles fue analizada utilizando Cromatografía Iónica (CI), Difracción de rayos-X (DRX) y Microscopía Electrónica de Barrido Ambiental con espectroscopía dispersiva de rayos-X (MEBA-EDX) para así caracterizar la mezcla salina asociada con el deterioro superficial.

Las sales presentes en las muestras de piedra fueron analizadas por DRX y MEBA, antes de la extracción por disolución para identificar las fases minerales presentes en las muestras, y después, una vez que las sales solubles fueron concentradas mediante evaporación. La MEBA permitió la detección de sales minoritarias que no aparecían por DRX. Cada muestra (0,5 g aprox.) fue diluida en $5 \mathrm{ml}$ de agua desionizada, agitando durante 1 minuto y dejando reposar durante 24 horas a temperatura ambiente. Esta muestra diluida se filtró a continuación para separar el agua y las sales solubles y finalmente se evaporó sobre una placa a $60^{\circ} \mathrm{C}$, dejando así que precipitase la sal.

La Cromatografía Iónica se utilizó para identificar las sales solubles los cationes y aniones presentes en las muestras de Howden. Este análisis nos permitió cuantificar los porcentajes de estas sales para replicar las mezclas en los experimentos de laboratorio en la cámara climática, y reproducir el proceso de laminación sobre diferentes tipos de calizas. Los análisis cuantitativos de sales solubles se llevaron a cabo con un cromatógrafo Dionex less than one year. One goal of this work is to determine if the flaking of the magnesian limestone used at Howden could be simulated in the laboratory solely by humidity cycling, since the role, extent and changes in liquid water within the wall due to capillarity rise are not yet clear.

\section{MATERIALS AND METHODS}

To evaluate the degree of active flaking in the field, at Howden Minster, visual analysis was made through photo documentation and the installation of a time-lapse field camera to correlate flaking events with environmental change.

In order to examine how salt phases and content related to damage, salts were extracted from three fractions of surface samples of weathered stone from the top arch of elevation 16 (bay 4 west wall) at Howden Minster; HBC16-A: stone powder; HBC16-B1: black crust fragments and HBC16-B2: stone flake fragments (Figure 1a). The extracts of soluble salts were analyzed using Ion Chromatography (IC), X-ray Diffraction (XRD) and Environmental Scanning Electron Microscopy with energy dispersive $X$-ray spectroscopy (ESEM-EDX) to characterize the salt mixture associated with surface damage.

Salts present in the stone samples were analyzed by XRD and ESEM, both before aqueous extraction to identify the mineral phases present in the samples, and after, once the soluble salts were concentrated by evaporation. The ESEM allowed detection of minor salts that were not present in XRD. Each sample ( $0.5 \mathrm{~g}$ approx.) was diluted in $5 \mathrm{ml}$ of deionized water, shaking for one minute and left for 24 hours at room temperature. This sample solution was then filtered to isolate water and soluble salts and finally evaporated over a hot plate at $60{ }^{\circ} \mathrm{C}$ leaving the salt precipitate.

Ion Chromatography was used to identify the soluble salts as cations and anions present in the samples from Howden. This analysis allowed us to quantify the percentages of these salts to replicate the mixtures for laboratory experiments to reproduce flaking in the climatic chamber on several types of limestones. Quantitative analysis of the soluble salts was performed on a Dionex DX-500 Chromatograph. An IonPac \#CS12A Analytical 4 
DX-500. Para la separación de cationes se uso una columna analítica de $4 \mathrm{~mm}$ IonPac\#CS12A. El eluyente fue $22 \mathrm{mN}$ de $\mathrm{H}_{2} \mathrm{SO}_{4}$, con una velocidad de flujo de $1 \mathrm{ml} / \mathrm{min}$, y un CSRS-ULTRA de $4 \mathrm{~mm}$ fue usado como supresor. Para la separación de cationes se usó una columna de 4 $\mathrm{mm}$ IonPac AS12A. El eluyente fue $1,8 \mathrm{mM} \mathrm{NaHCO}$ con una velocidad de flujo de $2 \mathrm{ml} / \mathrm{min}$, y un ASRS-ULTRA de $4 \mathrm{~mm}$ como supresor. Para la calibración se utilizó una mezcla de cationes y aniones.

La Microscopía Electrónica de Barrido Ambiental (MEBA) se llevó a cabo en un microscopio ESEM-FEG FEI XL30 (Hillsboro, Or) con espectroscopía dispersiva de rayos- $X$ (EDX) (modelo 7509 Oxford Instrument Analytical, UK). La MEBA-EDX se utilizó para analizar y observar la morfología de los cristales de las sales, para identificar y corroborar algunas de las sales menos abundantes que fueron aparentemente detectadas mediante los análisis de $\mathrm{CI}$, y para la realización de algunos experimentos variando la humedad relativa entre $30 \%$ y $95 \%$ para observar así el comportamiento de las sales ante estas fluctuaciones.

Las muestras también fueron estudiadas por Difracción de rayos-X (DRX). Estos análisis fueron llevados a cabo en un Siemens D5005 con una radiación CuK $\alpha$ y los difractogramas se obtuvieron mediante un barrido de medida desde $10^{\circ}$ a $60^{\circ} 2 \theta$ con un contaje de medida de $0,1^{\circ}$ y una velocidad de barrido de $8 \%$ min y $40 \mathrm{kV}$ y 30 $\mathrm{mA}$ en el tubo de rayos $\mathrm{X}$.

Finalmente, para los experimentos de laboratorio, siete tipos de piedra con dimensiones $4 \times 2,5 \times 2,5 \mathrm{~cm}$ fueron sumergida durante 24 horas en dos disoluciones salinas diferentes. El peso de las muestras y el porcentaje total del contenido de sales fueron registrados antes y después de la inmersión en la disolución salina.

Todas las piedras usadas en el experimento (Tabla 1) tienen una composición calcárea: (i) 5 tipos de calizas magnésicas: 3 especímenes procedentes de sus canteras locales originales en Reino Unido, Hazle Lane (HLQ), Highmoor (HMQ) y Cadeby (CDQ) con una porosidad accesible al agua del $18 \%, 25 \%$ y $21 \%$ respectivamente (25); y 2 especímenes procedentes de testigos tomados en los edificios históricos de York Minster (YK) y Howden Misnter (HW) de Reino Unido, cuya porosidad se encuentra en el mismo rango que las otras tres piedras $(19,25$, 26); (ii) 2 tipos de calizas (caliza Novelda) procedentes de las canteras de Bateig (España) las cuales han sido utilizadas en muchos edificios históricos españoles desde el siglo XIII. Dos variedades de caliza Bateig han sido utilizadas en este experimento, Bateig Blanca (BW) y Bateig Azul (BB) cuya porosidad accesible al agua es de alrededor del $17 \%$ y $15,7 \%$ respectivamente (27). $\mathrm{mm}$ column was used for the separation of cations. The eluent was $22 \mathrm{mN}$ of $\mathrm{H}_{2} \mathrm{SO}_{4}$, with a flow rate of $1 \mathrm{ml} / \mathrm{min}$, and a CSRS-ULTRA 4mm was used as the suppressor. An IonPac AS12A 4mm column was used for the separation of anions. The eluent was $1.8 \mathrm{mM} \mathrm{Na} \mathrm{CO}_{3} / 1.7 \mathrm{mM}$ $\mathrm{NaHCO}_{3}$, with a flow rate of $2 \mathrm{ml} / \mathrm{min}$, and an ASRSULTRA $4 \mathrm{~mm}$ was used as the suppressor. A mixture of cations and anions was used for calibration.

Environmental Scanning Electron Microscopy (ESEM) was performed in the samples using a XL30 ESEM-FEG FEI microscope (Hillsboro, OR) with energy dispersive $X$-ray spectroscopy (EDX) (model 7509 Oxford Instrument Analytical, UK). ESEM/EDX was used to analyze and observe the morphology of the salt crystals, to identify and to corroborate some of the less abundant salts that were apparently detected by IC analyses, and to performing some experiments changing the relative humidity between $30 \%$ and $95 \%$ to observe the behavior of the salts under these fluctuations.

The samples were also studied by $X$-ray Diffraction (XRD). These analyses were carried out in a Siemens D5005 with a CuKa radiation and patterns obtained by step scanning from $10^{\circ}$ to $60^{\circ} 2 \theta$ with a count of $0.1^{\circ}$ per step and a scan speed of $8 \% / \mathrm{min}$ and $40 \mathrm{kV}$ and $30 \mathrm{~mA}$ in the $X$-ray tube.

Finally, for the laboratory experiments, seven types of stone with dimensions $4 \times 2.5 \times 2.5 \mathrm{~cm}$ were immersed in two different salt solutions for 24 hours. The weight of the specimens before and after the immersion in the salt solution and the total percentage of salt content of the specimens immersed in the salt mixture solution were registered.

All the stones used in the experiment (Table 1) have a calcareous composition: (i) 5 types of magnesian limestone: 3 specimens from their original local quarries in United Kingdom, Hazel Lane (HLQ), Highmoor (HMQ) and Cadeby (CDQ) with a porosity accessible to water of $18 \%, 25 \%$ and $21 \%$, respectively (25); and 2 specimens from the cores of the historical buildings of York Minster (YK) and Howden Minster (HW) from United Kingdom, which porosity is in the same range as the other three stones $(19,25,26) ;$ (ii) 2 limestone types (Novelda Limestone) from Bateig quarries (Spain), which have been used in many historic Spanish buildings since the $13^{\text {th }}$ century. Two varieties of Bateig stone have been used in this experiment, Bateig White (BW) and Bateig Blue (BB) which porosity accessible to water is circa $17 \%$ and $15.7 \%$, respectively (27). 
Tabla 1 / Table 1

Muestras de calizas sumergida en disoluciones salinas antes de los ciclos de humedad Limestone specimens immersed in salt solutions before the humidity cycles

\begin{tabular}{|c|c|c|c|c|}
\hline \multirow{2}{*}{$\begin{array}{l}\text { Procedencia } \\
\text { (Provenance) }\end{array}$} & \multirow{2}{*}{$\begin{array}{l}\text { Muestras* } \\
\text { (Samples) }\end{array}$} & \multirow{2}{*}{$\begin{array}{l}\left(\mathbf{W}_{0}\right) \\
\text { Peso inicial }(g) \\
\text { (Initial weight) }\end{array}$} & \multirow{2}{*}{$\begin{array}{c}\left(\mathbf{W}_{1}\right) \\
\text { Peso final** }(\mathbf{g}) \\
\text { (Final weight) }\end{array}$} & \multirow{2}{*}{$\begin{array}{c}\begin{array}{c}\text { Total de disolución salina }\left(\mathbf{T}_{\mathbf{s s}}\right) \\
\text { absorbida }(\%)\end{array} \\
\text { (Total salt solution absorbed) }\end{array}$} \\
\hline & & & & \\
\hline \multirow{2}{*}{ York } & YK1 & 56.47 & 62.25 & 10.24 \\
\hline & YK2 & 56.18 & 61.83 & 10.06 \\
\hline \multirow{2}{*}{ Howden } & HW1 & 55.61 & 59.00 & 6.09 \\
\hline & HW2 & 55.87 & 59.27 & 6.08 \\
\hline \multirow{2}{*}{$\begin{array}{l}\text { Bateig azul } \\
\text { (Bateig Blue) }\end{array}$} & BB1 & 62.16 & 63.35 & 1.91 \\
\hline & BB2 & 62.44 & 63.48 & 1.67 \\
\hline \multirow{2}{*}{$\begin{array}{l}\text { Bateig blanco } \\
\text { (Bateig White) }\end{array}$} & BW1 & 56.34 & 60.73 & 7.79 \\
\hline & BW2 & 56.29 & 60.78 & 7.98 \\
\hline \multirow{2}{*}{$\begin{array}{l}\text { Hazel Lane Cantera } \\
\text { (Quarry) }\end{array}$} & HLQ1 & 64.59 & 67.42 & 4.38 \\
\hline & HLQ2 & 62.88 & 66.35 & 5.51 \\
\hline \multirow{2}{*}{$\begin{array}{l}\text { Highmoor Cantera } \\
\text { (Quarry) }\end{array}$} & HMQ1 & 61.99 & 65.23 & 5.23 \\
\hline & HMQ2 & 65.44 & 68.67 & 4.94 \\
\hline \multirow{2}{*}{$\begin{array}{l}\text { Cadeby } \\
\text { Cantera (Quarry) }\end{array}$} & CDQ1 & 64.25 & 70.10 & 9.11 \\
\hline & CDQ2 & 62.38 & 68.34 & 9.55 \\
\hline
\end{tabular}

${ }^{(*)}$ 1. Muestras sumergidas en solución supersaturada de sulfato magnésico (120wt\%). Samples immersed in magnesium sulfate supersaturated solution (120wt\%);

2. Muestras sumergidas en solución supersaturada de sulfato magnésico (120wt\%), Cloruro sódico (5,3wt\%) y sulfato cálcico (37wt\%). Samples immersed in magnesium sulfate supersaturated solution (120wt\%), Sodium Chloride (5.3wt\%) and Calcium Sulfate (37wt\%).

${ }^{(* *)}$ Peso final después de la inmersión de las muestras en las disoluciones salinas durante 24 horas. Final weight, after immersion of samples in the salt solutions during 24 hours.

Las dos disoluciones salinas utilizadas para la inmersión de las muestras consistieron en una solución de una única sal y de una mezcla de sales: (i) siete especimenes de cada tipo de piedra (YK1, HW1, BB1, BW1, HLQ1, HMQ1, CDQ1) fueron inmersos en una solución supersaturada con $1.200 \mathrm{~g} / \mathrm{l}$ de sulfato magnésico (120wt\%); (ii) siete especímenes de cada tipo de piedra (YK2, HW2, BB2, BW2, HLQ2, HMQ2, CDQ2) fueron inmersos en una disolución de mezcla de sales con $52,86 \mathrm{~g} / \mathrm{l}$ de cloruro sódico $(5,3 w t \%), 1.200 \mathrm{~g} / \mathrm{l}$ de sulfato magnésico (120wt\%) y $369,52 \mathrm{~g} / \mathrm{l}$ de sulfato cálcico (37wt\%) para simular la mezcla salina encontrada en la piedra de Howden.

Después de la inmersión, 5 caras del prisma de cada especimen fueron cubiertas con látex para dejar la muestra evaporar y permitir el intercambio de humedad por una sola cara. Todas las muestras fueron introducidas en una estufa a $40{ }^{\circ} \mathrm{C}$ durante 7 días para dejar precipitar las sales a través de la superficie de las piedras.

Con la finalidad de acelerar la alteración observada en el campo, las muestras se introdujeron en una cámara con control ambiental (Thermotron 2800) durante 50 días a temperatura ambiente $\left(20^{\circ} \mathrm{C}\right)$ sometidas a ciclos de 24
The two salt solutions used to immerse the samples were a single salt solution and a mixture of salts: (i) seven specimens of each type of stone (YK1, HW1, BB1, BW1, HLQ1, HMQ1, CDQ1) were immersed in a supersaturated solution with $1200 \mathrm{~g} / \mathrm{l}$ of magnesium sulfate $(120 \mathrm{wt} \%)$; (ii) seven specimens of each type of stone (YK2, HW2, $B B 2, B W 2, H L Q 2, H M Q 2, C D Q 2)$ were immersed in a salt mixture solution of $52.86 \mathrm{~g} / \mathrm{l}$ of sodium chloride (5.3wt\%), $1200 \mathrm{~g} / \mathrm{l}$ of magnesium sulfate (120wt\%) and $369.52 \mathrm{~g} / \mathrm{l}$ of calcium sulfate (37wt\%) to simulate the salt mixture found at Howden stone.

After impregnation, 5 faces of the prism of each specimen were coated with latex to let the sample evaporate and allowing moisture exchange only from 1 face. All the samples were placed in an oven at $40^{\circ} \mathrm{C}$ for 7 days to let the salts dry out through the surface of the stones.

In order to accelerate the weathering observed in the field, the samples were placed in an environmentally controlled chamber (Thermotron 2800) for 50 days at room temperature $\left(20^{\circ} \mathrm{C}\right)$ subject to cycles of 24 hours at $30 \%$ 
horas a $30 \%$ de humedad relativa (HR) y 24 horas a $95 \%$ HR y 15 días entre $30 \%$ y $50 \%$. Todos los especímenes se colocaron bajo un transductor electrónico para registrar el desplazamiento $(\mathrm{mm} / \mathrm{m})$ de las muestras debido a la expansión y contracción de la piedra en respuesta al cambio de la HR.

\section{RESULTADOS}

La toma de fotografías de campo de las muestras de piedra en el edificio, en intervalos de 16 meses, revela la pérdida de láminas y la creación de otras nuevas. Esto demuestra que el deterioro de la piedra en Howden está activo, incluso en áreas donde no hay eflorescencias salinas visibles (Figura 1a).

Los resultados de los análisis de Cromatografía de Iones (CI), Difracción de rayos-X (DRX) y Microscopía Electrónica de Barrido Ambiental (MEBA) de la extracción salina procedente de la disolución de las muestras de piedra y costra de superficie de la elevación 16 (crujía 4 muro oeste) en Howden muestran que el sulfato magnésico y sulfato cálcico, son las fases más abundante presentes, con cloruro sódico y nitrato sódico en menores concentraciones (por debajo de la sensibilidad de la DRX, pero detectadas mediante MEBA-EDX y CI). relative humidity $(\mathrm{RH})$ and 24 hours at $95 \% \mathrm{RH}$ and 15 days between $30 \%$ and $50 \%$. All the specimens were set up under an electronic transducer to record the displacement $(\mathrm{mm} / \mathrm{m})$ of the samples due to expansion and contraction of the stone in response to the $\mathrm{RH}$ change.

\section{RESULTS}

Field photographs of the stone samples in the building, taken 16 months apart, reveal the loss of flakes and the creation of new flakes. This demonstrates that the deterioration of the Howden stone is active, even in areas where no salt efflorescence is visible (Figure 1a).

The results from the analyses by Ion Chromatography (IC), X-ray Diffraction (XRD) and Environmental Scanning Electron Microscopy (ESEM) of the salt extracts from the dissolution of samples of stone and surface crust from elevation 16 (bay 4 west wall) at Howden show that magnesium sulfate and calcium sulfate, are the most abundant phases present, with sodium chloride and sodium nitrate present in lower concentrations (below XRD sensitivity, but detected by ESEM-EDX and IC).

Tabla 2 / Table 2

Análisis de cromatografía de iones de muestras de fragmentos de piedra tomados en Howden Minster Ion chromatography analyses of stone samples fragments taken from Howden Minster (UK)

\begin{tabular}{|c|c|c|c|c|c|c|c|c|c|c|}
\hline \multirow{2}{*}{$\begin{array}{l}\text { Muestras } \\
\text { (Samples) }\end{array}$} & \multicolumn{10}{|c|}{ Concentración de iones en las muestras (\%) / Concentration of ions in samples (\%) } \\
\hline & $\mathrm{Na}^{+}$ & $\mathrm{NH}_{4}^{+}$ & $\mathrm{K}^{+}$ & $\mathrm{Mg}^{2+}$ & $\mathrm{Ca}^{2+}$ & $\mathrm{F}^{-}$ & $\mathrm{Cl}^{-}$ & $\mathrm{NO}_{3}^{-}$ & $\mathrm{PO}_{4}^{3-}$ & $\mathrm{SO}_{4}{ }^{2-}$ \\
\hline HBC16-A & 0.02 & 0.00 & 0.01 & 0.10 & 1.00 & 0.00 & 0.04 & 0.10 & 0.00 & 3.11 \\
\hline \multirow[t]{3}{*}{ HBC16-B } & 0.01 & 0.00 & 0.01 & 0.04 & 0.78 & 0.00 & 0.01 & 0.03 & 0.00 & 2.23 \\
\hline & \multicolumn{10}{|c|}{ Microequivalentes por gramo / Microequivalents per gram } \\
\hline & $\mathrm{Na}^{+}$ & $\mathrm{NH}_{4}^{+}$ & $\mathrm{K}^{+}$ & $\mathrm{Mg}^{2+}$ & $\mathrm{Ca}^{2+}$ & $\mathrm{F}^{-}$ & $\mathrm{Cl}^{-}$ & $\mathrm{NO}_{3}^{-}$ & $\mathrm{PO}_{4}^{3-}$ & $\mathrm{SO}_{4}^{2-}$ \\
\hline HBC16-A & 9 & 0.0 & 3.7 & 80.6 & 501 & 0.0 & 12.1 & 17 & 0.0 & 647 \\
\hline HBC16-B & 6 & 0.0 & 2.8 & 34.5 & 387 & 0.0 & 4 & 5.4 & 0 & 465 \\
\hline
\end{tabular}

Los resultados de CI están recogidos en la Tabla 2. Los microequivalentes por gramo muestran un balance entre los aniones de $\mathrm{SO}_{4}{ }^{2-}$ y los cationes de $\mathrm{Mg}^{2}{ }^{+}$y $\mathrm{Ca}^{2}{ }^{+}$, sugiriendo la presencia de sulfatos magnésicos y cálcicos en las muestras.

El estudio por MEBA sobre la muestra de piedra pulverizada HBC16-A indica que el sulfato magnésico está principalmente presente como una masa esponjosa amorfa, y el cloruro sódico con hábitos cúbicos. El sulfato cálcico
The Ion Chromatography results are found in Table 2. The microequivalents per gram show a balance between $\mathrm{SO}_{4}{ }^{2-}$ anions and $\mathrm{Mg}^{2+}$ and $\mathrm{Ca}^{2}{ }^{+}$cations, suggesting the presence of magnesium and calcium sulfates in the samples.

Under the ESEM, sample of stone powder HBC16-A shows that magnesium sulfate is mainly present as an amorphous fluffy mass, and sodium chloride with cubic habits. Calcium sulfate is the most abundant phase, then 
es la fase más abundante, a continuación el sulfato magnésico y el cloruro sódico es escaso. Las muestras de fragmentos de costra negra HBC16-B1 contienen yeso que está presente como grandes cristales, con el sulfato magnésico precipitando alrededor de los bordes de los cristales 0 , en algunos casos, con formas de fichas de puzzle. No se ha observado cloruro sódico, pero los cristales de yeso y el sulfato magnésico aparecen incluídos en una matriz con una composición de $\mathrm{Na}, \mathrm{Cl}, \mathrm{Mg}$ y $\mathrm{Ca}$ que parece cementarlos. El sulfato cálcico es más abundante que el sulfato magnésico. Finalmente, los resultados de MEBA en los fragmentos de láminas de piedra, magnesium sulfate and sodium chloride is scarce. Sampled black crust fragments HBC16-B1 contain gypsum that is present as large crystals with magnesium sulfate precipitated around their edges or in some cases with puzzle shapes. No sodium chloride has been observed, but the gypsum and magnesium sulfate crystals are included in a matrix with a composition of $\mathrm{Na}, \mathrm{Cl}, \mathrm{Mg}$ and Ca that appears to cement them. Calcium sulfate is more abundant than magnesium sulfate. Finally, the ESEM results of the stone flake fragments, sample HBC16-B2, show small crystals of sodium chloride and sodium nitrate. Magnesium sulfate and calcium sulfate are the main
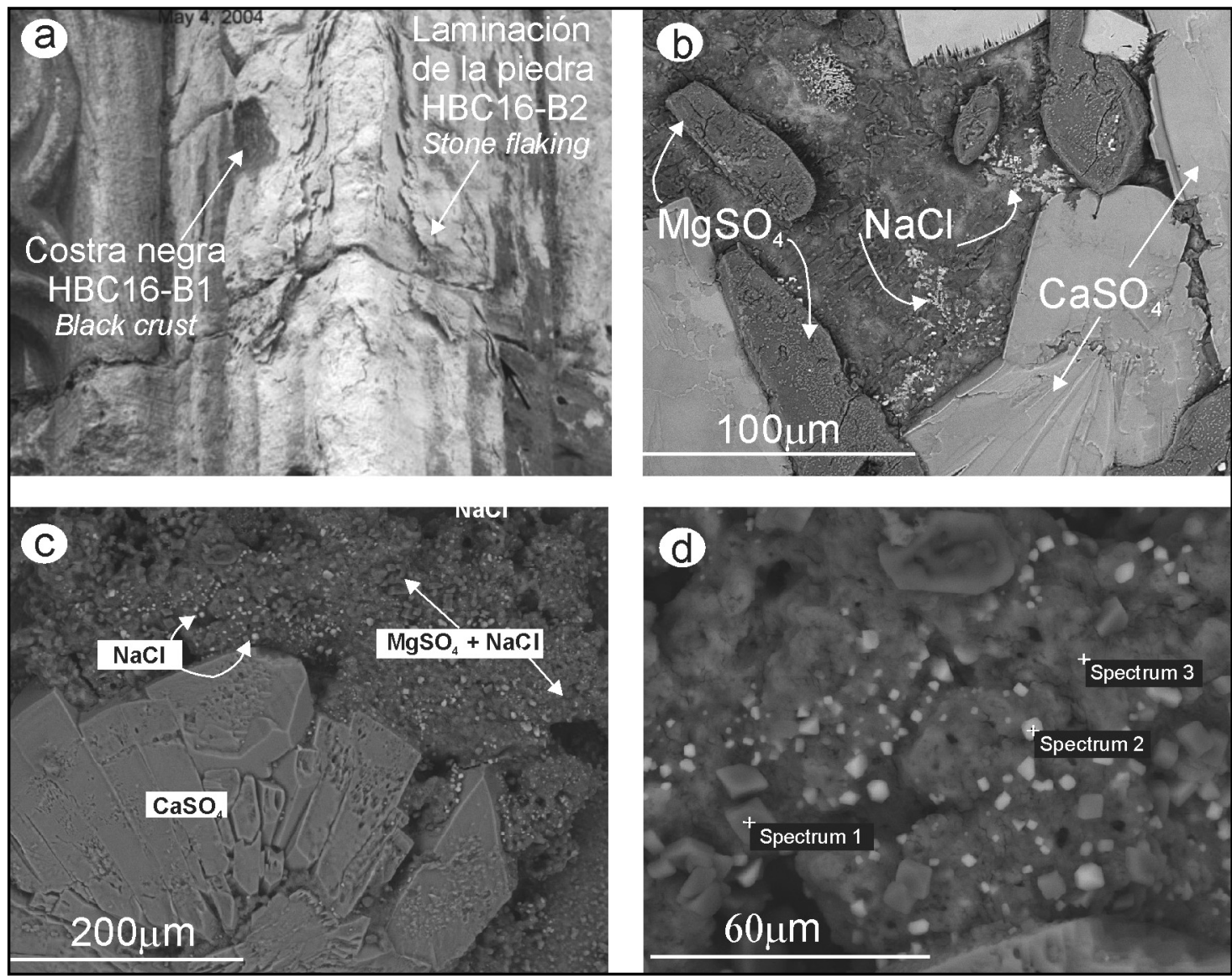

Figura 1. Howden Minster Chapter House (UK). a) Muestras de superficie de piedra alterada procedentes de la parte superior del arco de elevación 16 (crujía 4 muro oeste) de Howden Minster; HBC16-B1: fragmentos de costra negra y HBC16-B2: fragmentos de laminación de piedra; b) Análisis MEBA-EDX de extracción de sales procedentes de fragmentos de laminación de piedra, muestra HBC16-B2, mostrando pequeños cristales de cloruro sódico y presencia de menores cantidades de nitrato sódico (no visible en la imagen); c) Análisis MEBA-EDX de sales solubles extraídas de piedra pulverizada (muestra HBC16-A1) tras disolución durante $24 \mathrm{~h}$ con agua a $20^{\circ} \mathrm{C}$ e introducidas en el horno a $60^{\circ} \mathrm{C}$ hasta secarse. Precipitación de cristales de sulfato cálcico, mezcla de sulfato magnésico y cloruro sódico y cristales cúbicos de cloruro sódico; d) Detalle de la imagen 1c): Espectros de MEBA-EDX mostrando una mezcla de $\mathrm{Mg}, \mathrm{S}, \mathrm{Na}$ y Cl. Espectro 1: sulfatos de magnesio y sodio; espectro 2: cloruro sódico y sulfato magnésico; espectro 3: sulfato magnésico y cloruros.

Figure 1. Howden Minster Chapter House (UK). a) Surface samples of weathered stone from the top arch of elevation 16 (bay 4 west wall) at Howden Minster; HBC16-B1: black crust fragments and HBC16-B2: stone flake fragments; b) ESEM-EDX analysis of salt extraction from stone flake fragments, sample HBC16-B2, showing small crystals of sodium chloride and displaying minor amounts of sodium nitrate (not visible in the image); c) ESEM-EDX analysis of soluble salts extracted from stone powder (sample HBC16-A1) after $24 \mathrm{~h}$ dissolution with $20^{\circ} \mathrm{C}$ water and placed at $60^{\circ} \mathrm{C}$ in oven until dry. Precipitation of crystals of calcium sulfate, mixture of magnesium sulfate and sodium chloride and cubic crystals of sodium chloride; d) Detail of image 1c): ESEM-EDX spectrums showing a mixture of Mg, S, $\mathrm{Na}$ and $\mathrm{Cl}$. Spectrum 1: magnesium and sodium sulfates; spectrum 2: sodium chloride and magnesium sulfate; spectrum 3: magnesium sulfate and chlorides. 
muestra HBC16-B2, señalan pequeños cristales de cloruro sódico y nitrato sódico. El sulfato magnésico y el sulfato cálcico son las principales fases minerales presentes en las muestras (Figura 1b). Los resultados de los análisis de DRX confirman la presencia de sulfato cálcico (como yeso) y sulfato magnésico (como hexahidrita) en la muestra de fragmentos de laminación de piedra HBC16-B2. Los espectros de las muestras de piedra pulverizada $\mathrm{HBC} 16-\mathrm{A}$, y fragmentos de costra negra $\mathrm{HBC} 16-$ B1 sólo muestran yeso. Sin embargo, como se ha mencionado anteriormente, bajo espectros MEBA fueron observados grandes cristales de yeso, (Figura 1c) junto con sulfato magnésico con una textura plumosa y pequeños cristales cúbicos de cloruro sódico (Figura 1c y 1d).

Bajo MEBA se aplicaron ciclos de humedad relativa entre $30 \%$ y $95 \%$ a la mezcla de sal de sulfato magnésico, sulfato cálcico y cloruro sódico. El cloruro sódico cristaliza entre cristales de epsomita con forma de aguja que deshidratan por debajo de $50 \% \mathrm{HR}$, dando lugar a una superficie agrietada. El sulfato cálcico menos soluble está localizado debajo de la costra de epsomita. Esta mezcla salina fue también calentada a $40^{\circ} \mathrm{C}$ y analizada por DRX. Además de hexahidrita, yeso y halita se identificaron otras fases minerales, como bischofita (cloruro magnésico) y otras mezclas de sulfatos y cloruros magnésicos y sódicos.

Queríamos saber si la laminación de la caliza utilizada en Howden podría simularse únicamente por ciclos de humedad del sulfato magnésico. Los resultados en el laboratorio muestran que una incipiente laminación de las muestras de piedra caliza de Cadeby fue observada en 1,5 meses cuando el sulfato magnésico fue sometido a ciclos de entre $30 \%$ y $95 \%$ de humedad relativa.

Ambos especímenes-aquéllos sumergidos en la disolución de una única sal y los inmersos en la mezcla salina-absorbieron aproximadamente la misma cantidad de disolución salina (Tabla 1). Las muestras sumergidas en una única sal (sulfato magnésico) desarrollaron una costra cristalina gruesa y áspera sobre la superficie que incrementó en grosor durante el primer mes de ciclos de HR en la cámara climática. Las muestras sumergidas en la mezcla salina desarrollaron una costra fina y pulverizada sobre la superficie de las piedras. Esta costra fina se fue pelando hacia fuera con el comienzo de los ciclos de HR entre $30 \%$ y $95 \%$ hasta quedar casi despegada de la superficie al cabo de 1 mes. Después de 1 mes de ciclos, las muestras procedentes de la cantera de Cadeby (CDQ2) y York Misnter (YK2) mostraron laminaciones muy finas sobre la superficie de la piedra. Éstas fueron observadas en áreas donde la costra fina de sal estaba todavía presente, justo sobre la laminación, sugiriendo que los cambios dimensionales en la costra fina salina podrían estar favoreciendo el des- phases present in the samples (Figure $1 b$ ). The results from the XRD analyses confirm the presence of calcium sulfate (as gypsum) and magnesium sulfate (as hexahydrite) in sample of stone flake fragments $H B C 16-B 2$. The patterns for the samples of stone powder $H B C 16-A$, and black crust fragments HBC16-B1 only display gypsum. However, as we mentioned above under the spectra ESEM large crystals of gypsum were observed (Figure 1c) together with a feathery texture of magnesium sulfate and small cubic crystals of sodium chloride (Figure 1c and 1d).

Relative humidity cycles between 30\% and 95\% were applied under the ESEM to the salt mixture of magnesium sulfate, calcium sulfate and sodium chloride. Sodium chloride crystallizes in between needle shape crystals of epsomite that dehydrate below $50 \%$ RH, giving rise to a cracked surface. The less soluble calcium sulfate is located underneath the epsomite crust. This salt mixture was also heated at $40{ }^{\circ} \mathrm{C}$ and analyzed by XRD. Besides hexahydrite, gypsum and halite, other mineral phases were identified as bischoffite (magnesium chloride) and other mixtures of magnesium and sodium sulfates and chlorides.

We wanted to know if flaking of the limestone used at Howden could be simulated solely by humidity cycling of magnesium sulfate. The results show that incipient flaking of Cadeby limestone was observed in 1.5 months in stone samples when magnesium sulfate was cycled between $30 \%$ and $95 \%$ relative humidity in the laboratory.

Both specimens-those immersed in the single salt solution and in the salt mixture-absorbed approximately the same quantity of salt solution (Table 1). The samples immersed in the single salt (magnesium sulfate) developed a thick and coarsely crystalline crust over the surface that increased in thickness during the first month of $\mathrm{RH}$ cycling in the climatic chamber. The samples immersed in the salt mixture developed a fine and powdered crust over the surface of the stones. This thin crust was peeled outwards with the start of the $\mathrm{RH}$ cycles between $30 \%$ and $95 \%$ until it was almost detached from the surface after 1 month of cycling. After 1 month, the samples from Cadeby Quarry (CDQ2) and York Minster (YK2) showed very fine flakes on the surface of the stone. These were observed in areas where the fine salt crust was still present, just over the flake, suggesting that the dimensional changes in the thin salt crust could be aiding the development of the flakes. On the other hand, Cadeby Quarry (CDQ2) and York Minster (YK2) were the samples 
arrollo de las laminaciones. Por otro lado, las muestras de la cantera de Cadeby (CDQ2) y York Misnter (YK2) son aquéllas con mayores valores de absorción de solución salina, alrededor de $9 \%$ y $10 \%$ respectivamente. Las otras muestras absorbieron menos solución salina: Bateig Azul (BB) sólo cerca de un 2\% y Howden (HW) un 6\%.

Muestras de piedra sumergida en una solución de una única sal de sulfato magnésico:

La tendencia general de todas las curvas de transformación diferencial de variable lineal (TDVL) durante un mes y medio de ciclos de 24 horas a $30 \%$ HR y 24 horas a $95 \% \mathrm{HR}$ muestran una contracción en todas las muestras que varía entre 0,4 y $2 \mathrm{~mm} / \mathrm{m}$, con la excepción de la muestra de York Minster (YK1) la cual refleja una gran expansión de $6 \mathrm{~mm} / \mathrm{m}$ (Figura 2a). El desplazamiento medio de los TDVLs con cada ciclo de $24 \mathrm{~h}$ a $30 \%$ y $24 \mathrm{~h}$ a $95 \%$ está comprendido entre $\pm 0,1-0,3 \mathrm{~mm} / \mathrm{m}$. Durante la fase seca (a 30\%) se produce contracción, y durante la fase húmeda (desde $30 \%$ a $95 \% \mathrm{HR}$ ) las muestras se expanden. Después de 1,5 meses la humedad estuvo fluctuando entre $30 \%$ y $50 \%$. En este caso, las muestras ni expanden ni contraen. with higher salt solution absorption values, about $9 \%$ and $10 \%$ respectively. The other samples absorbed less salt solution: Bateig Blue (BB2) only ca. 2\% and Howden (HW2) 6\%.

\section{Samples of stone immersed in the single salt solution of magnesium sulfate:}

The general tendency of all the Linear Variable Differential Transformer (LVDT) curves during 1.5 months of cycling with 24 hours at $30 \%$ RH and 24 hours at $95 \%$ RH show a contraction in all the samples ranging between 0.4 and $2 \mathrm{~mm} / \mathrm{m}$, with the exception of sample from York Minster (YK1) which displayed a significant expansion of $6 \mathrm{~mm} / \mathrm{m}$ (Figure 2a). The average displacement of the LVDTs with each cycle of 24 hours at $30 \%$ $\mathrm{RH}$ and $24 \mathrm{~h}$ at $95 \%$ is ranging between $\pm 0.1-0.3 \mathrm{~mm} / \mathrm{m}$. During the dry phase (at 30\%) contraction occurs, and during the wetting phase (from $30 \%$ to $95 \% R H$ ) samples expand. After 1,5 months the humidity was fluctuating between $30 \%$ and $50 \%$. In this case, samples do not expand or contract.
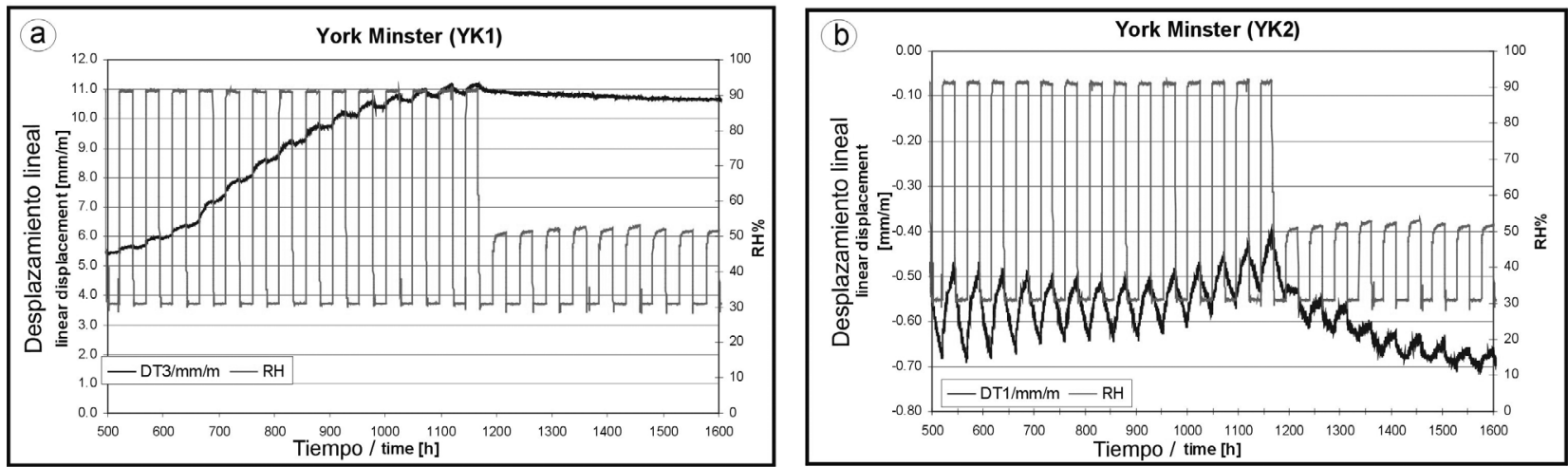

Figura 2. Gráficos mostrando los ciclos de humedad relativa HR (\%) y el desplazamiento lineal $(\mathrm{mm} / \mathrm{m})$ del Transformador Diferencial de Variable Lineal (TDVL) durante 50 días de ciclos de humedad relativa entre $30 \%$ y $95 \%$ y 15 días entre $30 \%$ y $50 \%$. a) Muestra de York Misnter YK1, sumergida en una disolución de una única sal de sulfato magnésico; Muestra de York Minster YK2, sumergida en una disolución de mezcla de sales de sulfato magnésico, sulfato cálcico y cloruro sódico.

Figure 2. Graphs showing the relative humidity cycling $\mathrm{RH}(\%)$ and the linear displacement $(\mathrm{mm} / \mathrm{m})$ of the Linear Variable Differential Transformer (LVDT) during 50 days of cycling the relative humidity between $30 \%$ and $95 \%$ and 15 days between $30 \%$ and $50 \%$. a) York Minster YK1 sample immersed in a single salt solution of magnesium sulfate; b) York Minster YK2 sample immersed in a mixture salt solution of magnesium sulfate, calcium sulfate and sodium chloride.

Muestras de piedra sumergida en una disolución salina mixta:

La tendencia general de todas las curvas de TDVL durante 10 días de ciclos de HR ( $24 \mathrm{~h}$ a $30 \%$ y después $24 \mathrm{~h}$ a $95 \%)$ muestran una contracción en todas las muestras de $0,1 \mathrm{~mm} / \mathrm{m}$, con la excepción de la muestra YK2 la cual presenta una ligera expansión de $0,05 \mathrm{~mm} / \mathrm{m}$. El despla-
Samples of stone immersed in the salt mixture solution:

The overall tendency of the LVDT curves during 10 days of $\mathrm{RH}$ cycling (24 hours at $30 \%$ and then 24 hours at 95\%) show a contraction in all the samples of $0.1 \mathrm{~mm} / \mathrm{m}$, with the exception of sample YK2 which displayed a slight expansion of $0.05 \mathrm{~mm} / \mathrm{m}$. The displacement of the LVDTs 
zamiento de los TDVLs con cada ciclo de $24 \mathrm{~h}$ a $30 \% \mathrm{HR}$ y $24 \mathrm{~h}$ a $95 \%$ varía entre $\pm 0,1-0,3 \mathrm{~mm} / \mathrm{m}$. Como en el caso de la muestras sumergidas en la disolución de una única sal, durante la fase de secado (a $30 \%$ ) se produce contracción, y durante la fase húmeda (desde $30 \%$ a $95 \% \mathrm{HR}$ ) las muestras se expanden. Después de 1,5 meses, durante la fluctuación de humedad entre $30 \%$ y $50 \%$, la muestra YK2 se contrajo 0,3 mm (Figura 2b).

Los resultados muestran que las piedras que sufrieron el mayor deterioro fueron aquellas sumergidas en la mezcla salina, siendo estas muestras las que desarrollaron laminaciones sobre la superficie (muestras CDQ2 y YK2). La principal diferencia en el comportamiento de estas muestras y aquéllas inmersas en la disolución de una única sal fue la contracción total de las muestras después de 1 mes de ciclos, entre 0,4 y $2 \mathrm{~mm} / \mathrm{m}$ en este caso, y sólo de 0,1 $\mathrm{mm} / \mathrm{m}$ para las muestras sumergidas en la mezcla salina. La contracción y expansión media $(\mathrm{mm} / \mathrm{m})$ con cada ciclo de $24 \mathrm{~h}$ a $30 \%$ HR y $24 \mathrm{~h}$ a $95 \%$ HR es muy similar en ambos casos. La causa del deterioro se supone que está relacionada con la disolución y recristalización de la mezcla salina durante las fluctuaciones en la HR entre $30 \%$ y $95 \%$.

\section{DISCUSIÓN}

El sulfato magnésico y el sulfato cálcico son las fases solubles más abundantes presentes en la caliza magnésica de Howden Minster, con cloruro sódico y nitrato sódico en menores concentraciones. Las fuentes de las sales solubles en Howden Minster parecen estar conectadas a contaminación aérea histórica y también a heces de pájaros. Investigaciones recientes sobre sales solubles procedentes de heces de pájaros han demostrado que contienen muchas más sales de cloruros, algunos sulfatos y muchos menos nitratos de lo que se esperaba (6). Shaffer en 1932 (19), cita la presencia de sulfatos procedentes de la combustión del carbón y también identificó cloruros en la ceniza negra sobre la superficie de la piedra en York Misnter.

Howden Minster está principalmente afectada por laminación de la piedra, la cual combinada con pulverización superficial es la huella de alteración más común encontrada en materiales de construcción porosos (28). El sulfato magnésico ha estado principalmente asociado con el proceso de laminación (19). En Howden Minster, se han generado profundos agujeros en el interior de la fábrica y este efecto erosivo es debido al deterioro físico por repetida disolución y recristalización de las sales, además de la reacción de la caliza con la lluvia ácida.

El hecho de que la muestra de fragmentos de laminación de piedra HBC16-B2 fuera la única con sulfatos cálcicos y magnésicos detectados por DRX, significa que se encon- with each cycle of $24 h$ at $30 \%$ RH and 24 hours at 95\% ranges between $\pm 0.1-0.3 \mathrm{~mm} / \mathrm{m}$. As in the case of samples immersed in the single salt solution, during the dry phase (at 30\%) contraction occurs, and during the wetting phase (from $30 \%$ to $95 \% R H$ ), samples expand. After 1.5 months, during humidity fluctuation between $30 \%$ and $50 \%$, sample YK2 contracted $0.3 \mathrm{~mm}$ (Figure $2 \mathrm{~b}$ ).

The results show that the stones that incurred the most damage were those immersed in the salt mixture, as they were the samples that developed flaking over the surface (sample CDQ2 and YK2). The main difference in the behavior of these samples and those immersed in the single salt solution was in the total contraction of the samples after 1 month cycling, between 0.4 and $2 \mathrm{~mm} / \mathrm{m}$ for single salt and only $0,1 \mathrm{~mm} / \mathrm{m}$ for salt mixture. The average contraction and expansion $(\mathrm{mm} / \mathrm{m})$ with each cycle of 24 $h$ at $30 \% R H$ and $24 h$ at $95 \% R H$ is very similar in both cases. The cause of the damage is expected to be related to deliquescence and recrystallization of the salt mixture during fluctuations in $\mathrm{RH}$ between $30 \%$ and $95 \%$.

\section{DISCUSSION}

Magnesium sulfate and calcium sulfate are the most abundant soluble phases present in the magnesian limestone of Howden Minster, with sodium chloride and sodium nitrate in lower concentrations. The sources of the soluble salts at Howden Minster appear to be connected to historic air pollution and bird droppings as well. Recent research on soluble salts from bird droppings has shown that they contain much more chloride salt, some sulfate and much less nitrate than expected (6). Shaffer in 1932 (19), cites the presence of sulfates from the coal burning and also identified chlorides in black soot on the stone surfaces at York Minster.

Howden Minster is mainly affected by flaking of the stone, which combined with surface powdering is the most common weathering pattern found on porous building materials (28). Magnesium sulfate has been mainly associated with flaking (19). In Howden Minster, deep holes have been gouged into the fabric and this erosive effect it is due to the physical damage by repeated dissolution and recrystallization of the salts, in addition to the reaction of the limestone with acid rain.

The fact that the sample HBC16-B2 of stone flake fragments was the only one with both calcium and magnesium sulfates detected by XRD, means that they were 
traban presentes en cantidades significantes y que probablemente jugaron un papel en el mecanismo de deterioro por laminación.

El sulfato magnésico es mucho más soluble que el sulfato cálcico. La solubilidad en agua a temperatura ambiente de la epsomita es casi 300 veces mayor que para el yeso. Esta mayor movilidad ayuda a explicar la mayor tasa de deterioro observada con el sulfato magnésico y su capacidad para penetrar hacia el interior de la piedra durante un típico ciclo humedad/secado (11). Por el contrario, el yeso tiende a formar costras de superficie más estables.

La epsomita es una sal muy soluble, frecuentemente capaz de convertir la humedad ambiente en agua líquida (29) y su solubilidad en agua incrementa rápidamente con la temperatura. La humedad relativa en el equilibrio (HReq) a $20^{\circ} \mathrm{C}$ de epsomita, en disoluciones puras es del $90,1 \%(30)$ y del $88,3 \%$ en sistemas componentes múltiples (31).

La típica mezcla salina muestreada en Howden Minster incluye yeso, sulfato magnésico con menores cantidades de cloruro sódico y nitrato sódico. A temperatura ambiente y a una presión de vapor menor del 50\% HR $(\sim 12,00 \mathrm{~mm} \mathrm{Hg})$ la epsomita se transforma en hexahidrita, así como cuando se alcanza una temperatura de $60^{\circ} \mathrm{C}$ (32 y 33$)$.

Los ciclos de humedad entre $30 \%$ y $90 \%$ aplicados a las muestras de caliza en la cámara climática causaron laminaciones en las muestras de la cantera de Cadeby (CDQ2) y York Minster (YK2). La contracción de las muestras durante la fase de secado (a $30 \%$ ) está probablemente relacionada con la evaporación de la solución salina, con una consecuente reducción del volumen total de la piedra. La expansión de las muestras durante la fase de humedad (desde 30\% a 95\% HR) está probablemente relacionada con la hidratación y disolución de las sales con el incremento del volumen total de piedra. Tres tendencias se superponen: una tendencia a corto plazo relacionada con los ciclos ambientales y una tendencia a mayor plazo relacionada con la evaporación neta, contracción y formación de una costra salina en la superficie de las muestras.

El comportamiento opuesto reflejado en la Figura 2a y $2 b$, donde la muestra procedente de York Misnter inmersa en la mezcla salina produce contracción y contrariamente, sumergida en la disolución de una única sal produce expansión después de los ciclos de humedad, puede ser explicado debido a la presencia de sales delicuescentes de baja humedad relativa en el equilibrio (HReq) en la mezcla salina que probablemente producen finas películas acuosas a menor HR. La formación de cloruros magnésicos y cloruros cálcicos, con HReq a $32 \%$ y $34 \%$ respectivamente, en la mezcla salina, puede explicarse present at significant quantity and that they probably played a role in the mechanism of decay by flaking.

Magnesium sulfate is much more soluble than calcium sulfate. The solubility in water for epsomite at room temperature is almost 300 times greater than for gypsum. This greater mobility helps explain the much greater damage rate observed with magnesium sulfate and its ability to penetrate further into stone during a typical wet/dry cycle (11). In contrast, gypsum tends to form more stable surface crusts.

Epsomite is a very soluble salt, frequently able to convert the ambient moisture into liquid water (29) and its solubility in water increases rapidly with temperature. The equilibrium relative humidity ( $\mathrm{RHeq}$ ) at $20^{\circ} \mathrm{C}$ of epsomite, in pure solutions has been reported as $90,1 \%$ (30) and as $88,3 \%$ in multi-component systems (31).

Typical salt mixtures sampled from Howden Minster include gypsum, magnesium sulfate with lesser quantities of sodium chloride and sodium nitrate. At room temperature and at a vapour pressure lower than 50\% RH ( 12.00 $\mathrm{mm} \mathrm{Hg}$ ) epsomite transforms to hexahydrite, as well as when a temperature of $60^{\circ} \mathrm{C}$ is reached (32 and 33).

The humidity cycles between 30\% and 90\% applied to the limestone samples in the climate chamber caused the flaking of samples from Cadeby Quarry (CDQ2) and York Minster (YK2). The contraction of the samples during the drying phase (at 30\%) is likely related to the evaporation of the salt solution with a consequent shrinkage of the total volume of the stone. The expansion of the samples during the wetting phase (from 30\% to $95 \% R H$ ) is likely related to the hydration and deliquescence of the salts with the increase of the total volume of the stone. Three trends overlap-a short-term trend related to the environmental cycling and a longer-term trend related to the net evaporation, shrinkage and formation of a salt crust at the surface of the samples.

The contrasting behavior reported in Figure $2 a$ and $2 b$, where sample from York Minster immersed in the salt mixture induces shrinking and conversely, the immersion in the single salt solution induces expansion after the humidity cycles can be explained due to the presence in the salt mixture of deliquescence salts of low equilibrium relative humidity ( $\mathrm{RHeq}$ ) that likely produce thin films of solution at lower $\mathrm{RH}$. The formation of magnesium chlorides and calcium chlorides, with $\mathrm{RHeq}$ at $32 \%$ and $34 \%$ respectively, in the salt mixture can explain why equilibrium is not reached in sample YK2 during the humidity 
porque el equilibrio no se alcanza en la muestra YK2 durante las fluctuaciones de humedad entre $50 \%$ y $30 \%$ (Figura 2b), ya que la disolución y cristalización de estas sales se produce por encima y por debajo de $33 \% \mathrm{HR}$. Mientras que la muestra YK1 (Figura 2a), que desarrolló una costra gruesa de sulfato magnésico, alcanza el equilibrio durante las mismas fluctuaciones. Junto con la mayor porosidad abierta de la piedra (que debe ser similar a Cadeby con un 19\%) deducida por el valor similar de solución salina absorbida por ambas (alrededor de $10 \%$ ) hace que YK2 y CDQ2 sean más vulnerables al deterioro que YK1 o las otras piedras.

Binda et al. (34), observaron que experimentos de ciclos de cristalización llevados a cabo con sulfato magnésico en ladrillos porosos mostraron más deterioro cuando los ciclos de alteración incluyeron una etapa de calentamiento a $60{ }^{\circ} \mathrm{C}$ además de la evaporación de las muestras a $50 \%$ HR. Atribuyeron el rápido deterioro a la etapa de deshidratación (hepta a hexahidrita) por la que pasa esta sal, además de la completa cristalización que tiene lugar a estas temperaturas. Los sulfatos magnésicos y cálcicos tienen varios estados de hidratación y las fluctuaciones de humedad podrían causar un estrés mecánico generado por la expansión y contracción como queda reflejado por las curvas de TDVLs, dando lugar a la laminación de la piedra. Esto podría explicar porque los especimenes inmersos en la mezcla salina presentaron más deterioro que los otros.

Para evaluar el potencial deterioro de la hidratación vs. cristalización, fueron llevados a cabo estudios de laboratorio de reacciones de expansión con caliza Portland $\left(\mathrm{CaCO}_{3} 99 \%\right)$ impregnada con una solución saturada de sulfato magnésico (11). Los ensayos de ciclos de humedad fueron realizados a $92 \%, 82 \%$ y $40 \%$ HR. La cristalización de sales dentro de los poros fue potencialmente más dañina para la piedra que la hidratación de los cristales ya formados, sin embargo, se observó que la repetición de ciclos de hidratación se tradujo en agrietamientos internos.

El efecto de las fluctuaciones de humedad y el diferente gradiente de la HR dentro y fuera de la piedra podría darse en el movimiento de la sal dependiendo de la orientación del gradiente. Estos movimientos podrían también contribuir al estrés en cizalla en los primeros milímetros de la superficie de la piedra y al desarrollo de laminaciones, en el plano común entre la piedra y el ambiente, con el mayor gradiente de HR (35).

La causa de deterioro de las piedras procedentes de la cantera de Cadeby (CDQ2) y York Misnter (YK2) se supone que está relacionada con la cristalización de la mezcla salina y las fluctuaciones en la HR entre $30 \%$ y $95 \%$ que fluctuations between $50 \%$ and $30 \%$ (Figure $2 \mathrm{~b}$ ), since dissolution and crystallization of these salts is produced above and below 33\% RH. While sample YK1 (Figure 2a), which developed a thick crust only of magnesium sulfate, reaches the equilibrium during the same fluctuations. Together with the higher free porosity of the stone (that might be similar to Cadeby with a 19\%) deduced by the similar value of salt solution absorbed by both of them (circa 10\%) makes YK2 and CDQ2 more vulnerable to damage than YK1 or the other stones.

Binda et al. (34), observed that experiments of crystallization cycles carried out with magnesium sulfate on porous bricks showed more damage when the weathering cycle included a heating stage at $60^{\circ} \mathrm{C}$ in addition to the evaporation of the samples at $50 \%$ RH. They attributed this faster deterioration to the dehydration stage (hepta to hexahydrite) this salt goes through, in addition to the complete crystallization that takes place at these temperatures. Magnesium and calcium sulfates have several hydration states and humidity fluctuations could cause a mechanical stress generated by expansion and contraction as reflected by the LVDTs curves, leading to the flaking of the stone. This could also explain why the specimens immersed in the salt mixture displayed more damage than the others.

In order to evaluate the damage potential of hydration vs. crystallization, laboratory studies of expansive reactions were carried out with Portland limestone $\left(\mathrm{CaCO}_{3}\right.$ 99\%) impregnated with a saturated solution of magnesium sulfate (11). Humidity cycling test were conducted at $92 \%, 82 \%$ and $40 \%$ RH. Salt crystallization within the pores was potentially more damaging to stone than hydration of crystals already formed, however, repeated hydration cycles were observed to result in internal cracking.

The effect of humidity fluctuations and the different $\mathrm{RH}$ gradient inside and outside the stone could result in salt movement depending on the orientation of the gradient. These movements could also contribute to shear stress in the first millimeters of stone surface and development of flaking, at the interface between the stone and the environment, with the strong $\mathrm{RH}$ gradient (35).

The cause of the damage of Cadeby Quarry (CDQ2) and York Minster (YK2) stones is expected to be related to crystallization of the salt mixture and the fluctuations in $\mathrm{RH}$ between $30 \%$ and $95 \%$ that cause the expansion and 
causan la expansión y contracción de la piedra. La contracción de las muestras durante la fase seca (a 30\% HR) está probablemente relacionada con la evaporación de la solución salina con una consecuente reducción del volumen total de la piedra. La cantidad de disolución salina absorbida por las muestras es aproximadamente la misma en el caso de las muestras sumergidas en la disolución de una única sal y aquéllas sumergidas en la mezcla salina. Pero las muestras que sufrieron más deterioro fueron aquellas muestras con la mayor capacidad de absorción de solución salina: cantera de Cadeby (CDQ2) y York Minster (YK2), en contraste con la muestra de Bateig Azul (BB2) que no presenta ningún deterioro y tiene el menor valor de absorción de disolución salina.

El deterioro causado por los ciclos de humedad en estos experimentos de laboratorio también parece ser resultado de los siguientes procesos: un periodo de disolución a alta HR seguido por un rápido secado que resulta en la cristalización de las sales a partir de una disolución supersaturada. Las laminaciones son producidas por la presión del crecimiento del cristal. La presencia de pequeños cristales anhedrales de hexahidrita bajo la superficie de las laminaciones es consistente con este modelo que ha sido discutido con más detalle en otros trabajos (36 y 37 ).

\section{CONCLUSIONES}

1- Una búsqueda bibliográfica ha revelado que la alteración salina por sulfato magnésico está más extendida de lo que previamente se pensaba. Claramente, esto no es un problema regional, pero parece ocurrir donde sea que haya fuentes de humedad y razonablemente estén presentes y puedan acumularse iones de sulfato y magnesio. El proceso de deterioro debido a ciclos repetidos de disolución y cristalización de sales de sulfato magnésico relativamente solubles es debido a la presencia de agua líquida o, más a menudo, delicuescencia a alta humedad, y las fluctuaciones entre alta y baja humedad relativa, parecen ser en gran parte responsables del deterioro observado.

2- Las fuentes de las sales en Howden Misnter parecen estar conectadas a la contaminación aérea regional histórica. El sulfato magnésico y el sulfato cálcico, son las sales más abundantes encontradas en las laminaciones de la caliza magnésica. El cloruro sódico y el nitrato sódico están presentes en concentraciones mucho menores. Principalmente se ha encontrado yeso en los fragmentos de la costra sobre la superficie de la piedra. Esta información sugiere que una mezcla de sales estuvo relacionada con el deterioro por laminación de la piedra de Howden Minster.

3- Los experimentos de laboratorio han mostrado que una mezcla salina produce deterioro más pronto por lami- contraction of the stone. The contraction of the samples during the dry phase (at 30\%) is likely related to the evaporation of the salt solution with a consequent shrinkage of the total volume of the stone. The quantity of salt solution absorbed by the samples is about the same in the case of samples immersed in the single salt solution and those immersed in the salt mixture. But the samples that suffered more damage were those samples with the greatest capacity for absorption of the salt solution: Cadeby Quarry (CDQ2) and York Minster (YK2), in contrast to the sample Bateig Blue (BB2) which displays no damage at all and has the lowest salt solution absorption value.

The damage caused by humidity cycles in these laboratory experiments also appears to result from the following process: a period of deliquescence at high $\mathrm{RH}$ followed by rapid drying results in the crystallization of salts from a supersaturated solution. The flakes are produced by the crystal growth pressure. The presence of small anhedral crystals of hexahydrite on the underside of flaking surfaces is consistent with this model that has been discussed in more detail in other works (36 and 37).

\section{CONCLUSIONS}

1- A survey of the literature has revealed that salt weathering by magnesium sulfate is more widespread than previously thought. Clearly, this is not a regional problem, but appears to occur wherever sources of moisture and reasonably soluble magnesium and sulfate ions are present and can accumulate. The process of damage due to repeated cycles of dissolution and crystallization of the relatively soluble magnesium sulfate salts is due to the presence of liquid water or, more often, deliquescence at high humidity, and the fluctuations between high a low relative humidity, appear to be largely responsible for the damage observed.

2- The sources of salts at Howden Minster appear to be connected to historic regional air pollution. Magnesium sulfate and calcium sulfate, are the most abundant phases found in the flakes of magnesian limestone. Sodium chloride and sodium nitrate are present in much lower concentrations. Mainly gypsum was found in the crust fragments over the stone surface. These suggest that a salt mixture was related to the damage by flaking of Howden Minster stone.

3- Laboratory experiments have shown that a salt mixture produces earlier damage by flaking of stone by humi- 
naciones de la piedra mediante fluctuaciones de humedad comparado con una única sal (sulfato magnésico) que tiende a formar una costra. Muestras de caliza magnésica procedentes de la cantera de Cadeby y York Minster (Reino Unido) tienen mayores valores de absorción de disolución salina que otras piedras examinadas en este estudio y que cuando estan sumergidas en una disolución salina mixta, que contiene sales delicuescentes de baja RHeq, sufren mayor deterioro por los ciclos de humedad que otras piedras.

4-Estudiando el comportamiento de sales sobre la piedra natural mediante el control de temperatura y humedad relativa con cámaras climáticas y otras técnicas analíticas de laboratorio, resulta esencial para entender los diferentes mecanismos de deterioro y tipos de alteración asociada bajo diferentes condiciones ambientales.

5- La reducción de la infiltración de humedad y el control ambiental de muros cargados de sales para minimizar los cambios de la humedad relativa son estrategias útiles para reducir el deterioro. Disminuir o eliminar la fuente de sulfatos también ofrece un potencial para reducir este daño. Finalmente, disminuir los niveles de sal en la caliza magnésica y morteros afectados por contaminación aérea pasada es un importante reto para la conservación que, en gran parte, está por resolverse.

\section{AGRADECIMIENTOS}

Esta investigación fue realizada como parte de un proyecto de investigación conjunto entre English Heritage y Getty Conservation Institute (GCI) sobre la Caliza Magnésica. Agradecemos a John Fidler y Seamus Hanna del English Heritage y a Jeanne Marie Teutonico del GCI por sus puntos de vista y sus esfuerzos para apoyar este estudio y el tratamiento de este importante problema. Los autores agradecen a la Consejería de Ciencia y Tecnología JCCM, Toledo, España y al Fondo Social Europeo, por la financiación de una beca post-doctoral para desarrollar este trabajo. Agradecemos a Gicomo Chiari, jefe del Departamento de Ciencia del GCI, que fue la institución anfitriona para la beca post-doctoral de Paula López-Arce. Gracias a Joy Keeney del Laboratorio de Materiales Inorgánicos (GCI) por su ayuda con los análisis de Cromatografía de Iones. También apreciamos la ayuda proporcionada por Javier García Guinea y Rafael Martínez del MNCN (CSIC) por la realización de algunos análisis de DRX y a Laura Tormo por algunos de los experimentos de MEBA. Finalmente, también estamos agradecidos al equipo del Centro de Información del GCI y a nuestros actuales y anteriores colegas del GCI por sus contribuciones a esta investigación: Ann Bourges, Stefan Simon y David Carson. dity fluctuations compared to a single salt (magnesium sulfate) that tends to form a crust. Samples of magnesian limestone from Cadeby quarry and York Minster (UK) with higher salt solution absorption values than other stones examined in this study and when immersed in salt mixtures, containing deliquescent salts of low RHeq, suffer greater damaged by humidity cycling than other stones.

4- Studying the behavior of salts on natural stone by controlling temperature and relative humidity with climate chambers and other laboratory analytical techniques, is essential to understanding the different mechanisms of decay and associated weathering types under different environmental conditions.

5- Reducing moisture infiltration and the environmental control for salt-laden walls to minimize the relative humidity changes are useful strategies for reducing damage. Decreasing or eliminating the source of sulfates also offers some potential for reducing damage. Finally, reducing salt levels in magnesian stone and mortar affected by past air pollution is an important conservation challenge that largely remains to be addressed.

\section{ACKNOWLEDGEMENTS}

This research was performed as part of a joint research project on Magnesian Limestone by English Heritage and the Getty Conservation Institute (GCI). We thank John Fidler and Seamus Hanna of English Heritage and Jeanne Marie Teutonico of the GCI for their vision and their efforts supporting the study and treatment of this important problem. The authors thank the Ministry of Science and Technology JCCM, Toledo, Spain and the European Social Fund, for supporting a post-doctoral fellowship to develop this work. We thank Giacomo Chiari, chief scientist of the GCI, which was the host institution for the post-doctoral fellow of Paula Lopez-Arce. Thank you to Joy Keeney from the Organic materials Lab (GCI) for her help with the Ion Chromatography analyses. We also appreciate the help provided from the MNCN (CSIC) by Javier Garcia Guinea and Rafael Martinez for the performance of some XRD analyses and by Laura Tormo for some of the ESEM experiments. Finally, we are also grateful to the staff from the GCI Information Center and to our current and former colleagues at the GCI for their contributions to this research: Ann Bourges, Stefan Simon and David Carson. 


\section{BIBLIOGRAFÍA / BIBLIOGRAPHY}

(1) Winkler, E. M.: "Egyptian Obelisks (Cleopatra's Needles) of New York City and London-Environmental History and weathering", Internationale Zeitschrift fur Bauinstandsetzen, no6 (1996), pp. 519-530.

(2) Alaimo, R., Di Franco, L., Gagliardo Briuccia, V., Giarrusso, R., Montana, G.: "Plasters of the historical buildings of Palermo (Sicily): Raw Materials, causes and mechanisms of decay". IV Int. Sym. on the Conservation of Monuments in the Mediterranean Basin. 53-64, Rhodes, (1997).

(3) El-Metwally, A. A., Ramadan, A. B.: "The role of air pollutants and sewage waste in acceleration of degradation of the Islamic cultural heritage of Cairo", Comparative Risk Assessment and Environmental Decision Making. pp. 367-374. Kluwer Academic Publishers, Dordrecht, (2003).

(4) Livingstone, R. A.: "Influence of evaporite minerals on gypsum crusts and alveolar weathering". III Int. Sym. on the Conservation of Monuments in the Mediterranean Basin. 101-107, Venezia, (1994).

(5) Fitzner, B., Heinrichs, K.: "Damage diagnosis at monuments carved from bedrocks in Petra, Jordan". III Int. Sym. on the Conservation of Monuments in the Mediterranean Basin. 663-672, Venezia, (1994).

(6) Gómez-Heras, M., Benavente, D., Alvarez De Buergo, M., Fort R.: "Soluble salt minerals from pigeon droppings as potential contributors to the decay of stone based Cultural Heritage", Eur. J. Mineral., n016 (2004), pp. 505-509.

(7) Laue, S., Böhm, C. B., Jeannette, D.: "Salt weathering and. porosity-examples from the crypt of St. Maria im kapitol, Cologne". 8th Int. Cong. on Deterioration and Conservation of Stone. 513-522, Berlin, (1996).

(8) Cooke, R. U.: "Salt Weathering and the Urban Water Table in Deserts", Rock Weathering and Landform Evolution, p. 519, John Wiley \& Sons, Chichester, (1994).

(9) Linnow, K., Zeunert, A., Steiger, M.: "Investigation of Sodium Sulfate Phase Transitions in a Porous Material Using Humidity and Temperature-Controlled X-ray Diffraction", Anal. Chem. no 78 (2006), pp. 4683-4689.

(10) Charola, A. E., Lewin, S. Z.: "Efflorescences on building stones-SEM in the characterization and elucidation of mechanisms of formation", Scan. Electr. Microsc. n01 (1979), pp. 379-386.

(11) Cooke, R. U., Gibbs, G. B.: "Crumbling Heritage? Studies of stone weathering in polluted atmospheres", p. 68, National Power plc and PowerGen plc, Swindon, (1993).

(12) Benavente, D., Garcia del Cura, M. A., Garcia-Guinea, J., Sanchez-Moral, S., Ordoñez, S.: "Role of pore structure in salt crystallisation in unsaturated porous stones", J. Cryst. Growth., no 260 (2004), pp. 532-544.

(13) Cultrone, G., Russo, L. G., Calabrò, C., Uroševič1, M., Pezzino A.: "Influence of pore system characteristics on limestone vulnerability: a laboratory study", Environ. Geol., ISSN 0943-0105 (Print) 1432-0495 (Online) (2007).

(14) Ruiz-Agudo, E., Mees, F., Jacobs, P., Rodriguez-Navarro, C.: "The role of saline solution properties on porous limestone salt weathering by magnesium and sodium sulfates. Environ. Geol, Vol. 52, no 2 (2007), pp. 269-281.

(15) Sherman, L. A., Barak, P.: "The solubility and dissolution kinetics of dolomite $\left[\mathrm{CaMg}\left(\mathrm{CO}_{3}\right)_{2}\right]$ in Ca-Mg- $\mathrm{HCO}_{3} / \mathrm{CO}_{3}$ solutions at $25{ }^{\circ} \mathrm{C}$ and 0.1 MPa carbon dioxide", Soil Sci. Soc. Am. J., no 64 (2000), pp. 1959-1968.

(16) Caner, E. N., Demirci, S. A., Turkmenoglu, G.: "Deterioration of dolomite by soluble salts in Divrigi Mosque-Turkey". 5th Int. Cong. On Deterioration and Conservation of Stone. 299-305, Lausanne, (1985).

(17) Blanco-Varela, M. T., Menéndez, E., Hoyos, M.: "Study of surface decay of the marbles and serpentine from the Descalzas Reales Convent at Madrid". II Int. Sym. on the Conservation of Monuments in the Mediterranean Basin. 167-175, Geneve, (1991).

(18) Storemyr, P.: "A study on the weathering of Norwegian Greenschist". 8th Int. Cong. on Deterioration and Conservation of Stone. 489-495, Berlin, (1996).

(19) Schaffer, R. J.: "The weathering of Natural Building Stones", p.149, His Majestys Stationery Office, London, (1932).

(20) Laurie, A. P.: "Stone decay and the preservation of buildings", J. Soc. Chem. Ind., no 27 (1925), pp. 86-92.

(21) Martin, L., Bello, M. A., Martin, A.: "The efflorescences of The Cathedral of Almería". 7th Int. Cong. On Deterioration and Conservation of Stone. 869-873, Lisbon, (1992).

(22) Carretero, M. I., Galán, E.: "Marine spray and urban pollution as the main factors of stone damage in the cathedral of Málaga (Spain)". 8th Int. Cong. On Deterioration and Conservation of Stone. 311-324, Berlin, (1996).

(23) Fort, R., Varas M.J., Pérez-Monserrat, E., Vázquez-Calvo, C.: "Hexahidrita-epsomita en el deterioro de piedra dolomítica del patrimonio arquitectónico". "Hexahydrite-epsomite on dolomitic stone decay in the architectonic heritage". XXV Reunión de la Sociedad española de Mineralogía. 77-79, Alicante, (2005).

(24) González Limón, T., Álvarez de Buergo Ballester, M.: "Los revocos de cal de las fachadas de la plaza de la Corredera de Cordoba The lime renderings from plaza de la Corredera, Cordoba", Mater. Construcc., Vol. 52, no 267 (2002), pp. 19-30.

(25) Bourges, A., Doehne, E., Carson, D., Hanna, S., Martin, W.: "Physical-mechanical properties and decay mechanisms of magnesian limestones of northern England used for stone replacement". Work in progress (2007).

(26) Lott, G. K., Richardson, C.: "Yorkshire stone for building the Houses of Parliament (1839-c.1852)". Proceed. of the Yorkshire Geological Society, 51:265-272, London, (1997).

(27) Fort, R., Bernabeu, A., Del Cura, M. A., López de Azcona, M. C., Ordoñez, S., Mingarro, F.: "La piedra de Novelda: una roca muy utilizada en el patrimonio arquitectónico". "Novelda Stone: widely used within the spanish architectural heritage", Mater. Construcc., Vol. 52, no 266 (2002), pp. 19-32.

(28) Charola, A. E.: "Salts in the deterioration of porous materials: an overview", J. Am. Inst. Conserv., Vol. 39, no 3 (2000), pp. $327-343$.

(29) Sanjeev, T., Lal Gauri, K., Suhan, L., Cobourn, W. G.: "Kinetic study of $\mathrm{SO}_{2}$ reaction with dolomite", Environ. Sci. Technol., no 25 (1991), pp. 2071-2075. 
(30) Arnold, A., Zehnder, K.: "Decay of stony materials by salts on humid atmosphere". 6th Int. Cong. On Deterioration and Conservation of Stone. 138-148, Torun, (1988).

(31) Arnold, A., Zehnder, K.: "Salt weathering on monuments". I Int. Sym. on the Conservation of Monuments in the Mediterranean Basin. 31-58, Bari, (1989).

(32) Juling, H., Kirchner, D., Bruggerhoff, S., Linnow, K., Steiger, M., El Jarad, A., Gulker, G.: "Salt damage of porous materials: a combined theoretical and experimental approach". 10th Int. Cong. On Deterioration and Conservation of Stone. 187-194, Stockholm, (2004).

(33) Phadnis, A. B., Deshpande, V. V.: "On the dehydration of $\mathrm{MgSO}_{4} 7 \mathrm{H}_{2} \mathrm{O}^{\prime}$, Thermochim. Acta, no 43 (1981), pp. 249-250.

(34) Binda, L., Baronio, G., Charola, A. E.: "Deterioration of porous materials due to salt crystallization under different thermohygrometric conditions. I. Brick". 5th Int. Cong. On Deterioration and Conservation of Stone. 279-287, Lausanne, (1985).

(35) López-Arce, P., Doehne E.: "Kinetics of sodium sulfate efflorecence as observed by humidity cycling with ESEM". Proceed. Int. Conf. on Heritage, Weathering and Conservation. 285-291, Madrid, (2006).

(36) Rodriguez-Navarro, C., Doehne E.: "Salt weathering: influence of evaporation rate, supersaturation and crystallization pattern." Earth Surf. Proc. Land. Vol. 24, no 3 (1999), pp. 191-209.

(37) Doehne, E., Selwitz, C., Carson D.: "The damage mechanism of sodium sulfate in porous stone". Proceed. of the SALTeXPERT Meeting. 27-146, Prague, (2006). 